\title{
Tumor burden and cisplatin treatment alters the expression levels of microRNA-146a and -155 in spleen and cancer cells in an experimental mouse model of Ehrlich ascite carcinoma
}

\author{
Mohamed L. Salem ${ }^{* 1,2}$, Samar El Kholy ${ }^{1}$, Afaf Al-Atrash ${ }^{1}$, Duaa Samy ${ }^{1}$ \\ ${ }^{1}$ Department of Zoology, Faculty of Science, Tanta University, Tanta, Egypt \\ ${ }^{2}$ Center of Excellence in Cancer Research (CECR), Tanta New Teaching Hospital, Tanta University, Tanta, Egypt
}

Received: November 30, 2015

DOI: $10.5430 /$ jst.v6n1p78
Accepted: January 6, 2016

Online Published: Feburary 3, 2016

URL: http://dx.doi.org/10.5430/jst.v6n1p78

\begin{abstract}
Background: MicroRNAs (miRNAs) are small noncoding RNAs that typically inhibit translation and stability of messenger RNAs (mRNAs) and as such control expression of genes involved in different cellular processes. Several miRNAs have been linked to cancer and immune cells but whether there is a correlation between their expressions in both cells is still indistinct. Aim: In this study, we aimed to analyze miRNAs in tumor and immune cells in tumor bearing mice treated with or without chemotherapy.

Methods: CD1 mice were inoculated with intraperitoneal (i.p.) injection of $10^{6}$ viable cells from Ehrlich ascetic carcinoma (EAC) cell line to form ascities. Mice were then i.p. treated with PBS ascontrol or with cispaltin (10 or $40 \mu \mathrm{g} / \mathrm{mouse}$ ). Semiquantification of miRNAs 146a and 155 in spleen and tumor cells was done after 1 or 2 weeks of treatments using RT-PCR.

Results: The transcription level of miRNA-146a decreased in EAC and spleen cells, while miRNA-155 expression level increased. In EAC-bearing mice treated with CIS for 1 week, miRNA-155 expression level considerably increased in spleen and tumor cells as compared to tumor-non-bearing and untreated tumor-bearing mice. In contrast, the miRNA-146a transcription level decreased in both spleen and tumor cells as compared to its expression level in naive and untreated EAC- bearing mice. Two weeks post CIS treatment of EAC-bearing mice, spleen cells still show low expression levels of miRNA-146a, while theexpression levels of miRNA-155 increased in both spleen and tumor cells. Taken together, these results suggest that miRNA expression is significantly altered by tumor progression and by chemotherapy.
\end{abstract}

Key Words: MiRNA-155, MiRNA-146a, Ehrlich ascetic carcinoma, CIS treatment

\section{INTRODUCTION}

MicroRNA (miRNA) is an abundant class of small noncoding RNAs that are involved in various biological processes and human diseases by negatively regulating the translational efficiency and stability of their target mRNAs. ${ }^{[1]}$
Because of their wide variety of targets, miRNAs have been found to be involved in numerous developmental processes within cells including hematopoietic lineage differentiation, immunity, inflammation and tumorigenesis. ${ }^{[1-4]}$ MiRNAs were initially discovered in Caenorhabditis elegans as short

\footnotetext{
*Correspondence: Prof. Mohamed L. Salem, PhD; Email: mohamed.labib@ science.tanta.edu.eg; Address: Immunology \& Biotechnology Division Zoology Department, Faculty of Science, Center of Excellence in Cancer Research, Tanta New Teaching Hospital, Tanta University, Tanta, Egypt.
} 
strands of small non-coding RNAs 21 nucleotide. ${ }^{[5]}$ miRNAs mediate posttranscriptional gene regulation by pairing with the 3'untranslated region (3'UTR) of messenger RNAs (mRNAs), acting as regulating gene expression posttranscriptionally. ${ }^{[6]}$ MiRNAs control cell functions by silencing genes or gene clusters and may inhibit RNA translation by mRNA uncapping and deadenylation, which lead to increased mRNA turn over and decreased target gene expression. ${ }^{[7]}$

Given that miRNAs play a key role in diverse biological processes, their deregulated expression plays very important role in various diseases. ${ }^{[6]}$ MiRNAs that are involved in tumorigenesis and cancer are classified as oncomiRs. Those miRNAs are not only therapeutic targets, but also are considered important biomarkers for cancer detection and management. ${ }^{[8]}$

Among the known oncomiRs (miRNAs that lead to tumorigenesis and cancer), miRNA-155 is well known. Using genetic approaches, miRNA-155 has been demonstrated to have an indispensable role in humoral and cellular immunity ${ }^{[4,9-14]}$ and for this reason it has been linked to the development of leukemia, breast, lung and stomach tumors. ${ }^{[15]}$ However, the specific mechanism of its action was not known until recently. MiRNA-146a is one of a few of many examples of miRNAs involved in inflammation ${ }^{[16]}$ autoimmune disorders (miRNA21, miRNA-155). ${ }^{[17,18]}$ MiRNA-146a is involved in the regulation of innate immunity induced inflammatory response through modulating the expression of target genes. ${ }^{[16-19]}$

To understand the role of miRNA in antitumor responses and the associated immune responses, we have investigated in this study the expression profile of miRNA-146a and -155; as representative miRNA; in tumor and spleen cells before and after anti-cancer chemotherapy. The results conclude that these miRNA are modulated by the presence of tumor, the tumor volume as well as chemotherapy.

\section{MATERIAL AND METHODS}

\subsection{Mice}

All experiments were performed on adult female CD1 mice weighted 20 grams and aged between 8-16 weeks. The mice were purchased from Theodore Bilharz Research Institute (Cairo, Egypt). Mice were acclimatized at least two weeks before experimentation and randomly divided into the experimental groups, 10-12 mice for each. Mice were maintained at regular light and dark cycles, and provided with standard food and water ad libitum. This work was done based on the guidelines for the use of experimental animals in research at Department of Zoology, Faculty of Science, Tanta University, Egypt.

\subsection{Chemical and reagents}

Cisplatin (cis-diamminedichloroplatinum (II); CIS) was reconstituted in distilled water and stored at $4^{\circ} \mathrm{C}$ until used. Phosphate buffer saline (PBS) and trypan blue was prepared fresh. All reagents and chemicals were purchased from Sigma Aldrich Co., USA.

\subsection{Ehrlich ascites tumor model}

Ehrlich ascitic carcinoma (EAC) is a transplantable, poorly differentiated malignant carcinoma cell line which appears originally as a spontaneous breast carcinoma in CD1 mice. It grows in a solid or an ascitic form. CD1 mice were used to establish our own line through in vivo serial transplantation for tumor growth. Tumor cell suspensions were prepared in phosphate buffer saline (PBS) at final concentrations of $2.5 \times 10^{6}$ viable EAC/ml. In all experimental protocols described, mice were inoculated with intraperitoneal (i.p.) injection on day 0 with $10^{6}$ viable EAC cells per mouse in a volume of $0.2 \mathrm{ml}$. EAC viability, assessed by the trypan blue dye exclusion method, was always found to be $95 \%$ or more.

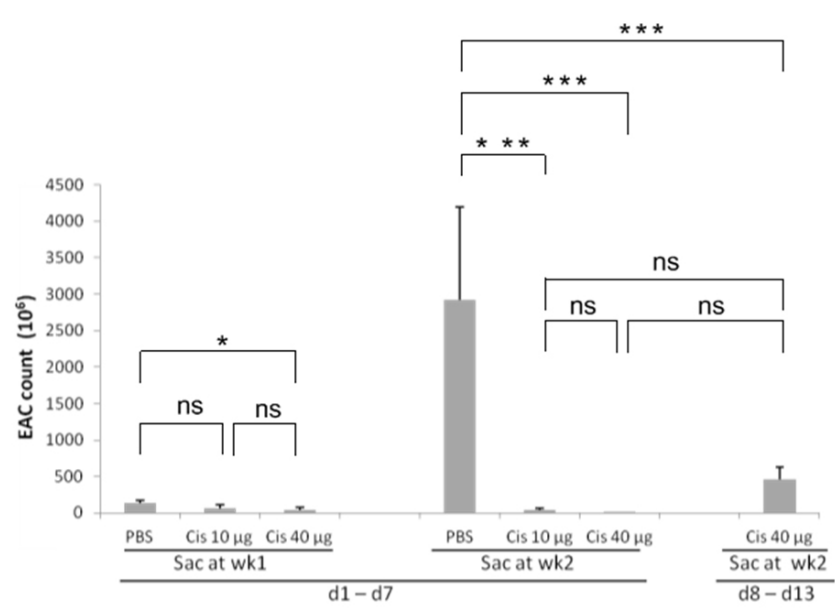

Figure 1. Effects of CIS treatment on the numbers of tumor cells. Mice were challenged with $10^{6}$ EAC cells through i.p. injection (day 0) and then treated with 10 or $40 \mathrm{ug}$ CIS/mouse as described in the Materials and Methods. The mice were sacrificed on day 14 post tumor challenge to count the total yield of EAC cells in the peritoneal exudates cells. Data are presented as mean $\pm S D .{ }^{*} P \leq .01$ as compared to control.

\subsection{Treatment of EAC-bearing mice with CIS}

Naive mice ( $n=6$ group) were challenged with $10^{6}$ EAC cells through i.p. injection (day 0). One group was i.p. treated with PBS as a positive control. Mice were i.p. treated with PBS or CIS (10 or $40 \mu \mathrm{g} / \mathrm{mouse}$ ) on days $1,3,4,5$, and 6 post tumor challenges and then sacrificed either on day 7 
or on day 14 of treatment (see Figure 1). Another group was challenged with $10^{6}$ EAC cells through i.p. injection (day 0), treated with $40 \mu \mathrm{g} /$ mouse CIS on days 8, 10,11, 12 and 13 and then sacrificed on day 14 . Tumor cells from the ascetic fluid as well as splenocytes from spleen were harvested from all animals for PCR analysis.

\subsection{Preparation of splenocytes}

The spleen cells were passed through $100-\mu \mathrm{m}$-pore-size nylon mesh filters (BD Biosciences, CA, USA) to obtain a single cell suspension of splenocytes. Erythrocytes were then depleted with ammonium chloride-potassium chloride (ACK; Invitrogen, Carlsbad, CA) buffer. ${ }^{[20]}$ Spleen suspension was prepared and counted using hemocytometer after staining with trypan blue dye exclusion to identify viable from dead cells.

\subsection{Assessment of tumor growth}

Seven days or fifteen days after i.p implantation $\left(10^{6}\right.$ EAC cells), mice were sacrificed and EAC cells were collected. Tumor cells were grown slowly from day 1 to 7 post cell inoculation and then aggressively after day 7 onward. To insure that all tumor cells were harvested, the peritoneal cavity was washed twice by $5 \mathrm{ml}$ PBS and all cells were pooled. Cells were washed for at least twice. After making an appropriate dilution, total number of tumor cells was determined with trypan blue exclusion assay. Harvested cells were diluted with saline $(0.9 \%)$ to the required concentration used in each experiment and counted with hemocytometer.

\subsection{RNA extraction and cDNA syntheses}

Total RNA, containing miRNA, was extracted from spleen and tumor cells from control and treated samples using RNA extraction kit (Thermoscientific) according to the manufacturer's protocol. First strand cDNA Synthesis Kit (Thermoscientific) was used according to the manufacturer's protocol using oligo(dT) 18 primers. The reaction was terminated by heating at $70^{\circ} \mathrm{C}$ for $5 \mathrm{~min}$. and the reverse transcription product was used directly in PCR amplification.

\subsection{RT-PCR}

PCR analysis for miRNA-146a and miRNA-155 were described previously (Wang P, 2010). RT primer for miRNA155 was miRNA-155 F: 5' CTC GTG GTT AAT GCT AAT TGTGA and miRNA-155 R: 5'-GTGCAGGGTCCGAGGT. The expression of pri-miRNA-146a was determined with the following primers: 5'-GAG ATT ACA GGC TTG CAC CAC A-3' (forward) and 5'-TGCCAG CAG TTC CAC GCT TCA C-3' (reverse). The following PCR conditions were used: initial denaturation at $94^{\circ} \mathrm{C}$ for $3 \mathrm{~min} ; 94^{\circ} \mathrm{C}$ for $30 \mathrm{~s}$, $55^{\circ} \mathrm{C}$ for $30 \mathrm{~s}, 72^{\circ} \mathrm{C}$ for $1 \mathrm{~min}$, for 35 cycles; final extension at $72{ }^{\circ} \mathrm{C}$ for $10 \mathrm{~min}$ were performed. All reactions were performed in triplicate. After PCR, products were separated on an ethidium bromide-stained $1 \%$ agarose gel. The band intensity as indicator of the relative expression of miRNA-146a and miR-155 was calculated using Image ${ }^{\circledR}$ software.

\subsection{Statistical analysis}

Numerical data obtained from each experiment were expressed as mean $\pm S D$. Using GraphPad Prism version 4.0 software, statistical differences between experimental and control groups were assessed using the Student $t$-test. $P$ values less than .05 were considered statistically significant.

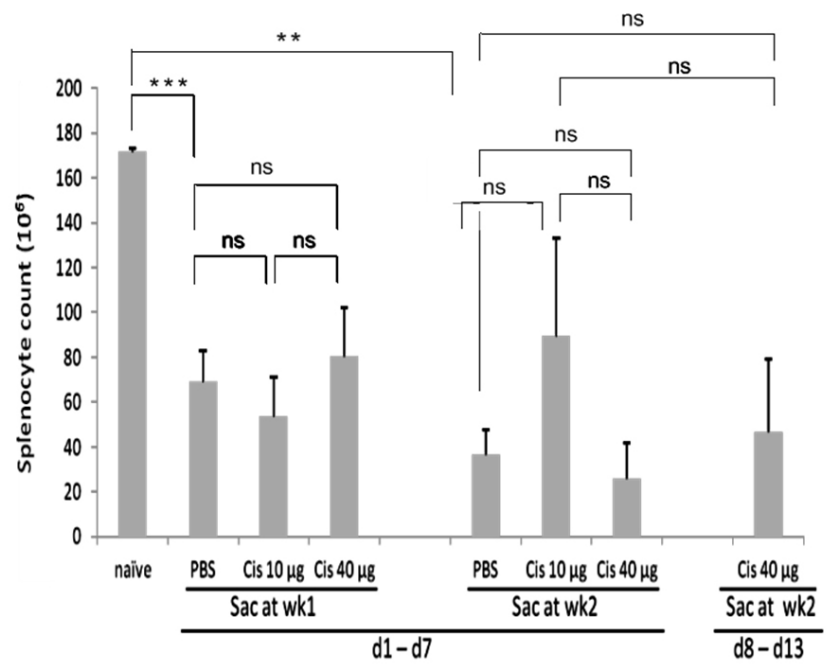

Figure 2. Effects of CIS treatment on the total numbers of splenocytes. Mice were i.p. treated with PBS or CIS (10 or $40 \mu \mathrm{g} /$ mouse) on days $1,3,4,5$, and 6 post tumor challenges and then sacrificed on day 7 post tumor challenge and then sacrificed either on day 7 or on day 14. Another group was challenged with $10^{6}$ EAC cells through i.p. injection (day 0) and then treated with $40 \mu \mathrm{g} / \mathrm{mouse}$ CIS on days $8,10,11,12$ and 13 and then sacrificed on day 14 .

\section{RESUltS}

\subsection{CIS treatment induced anti-tumor effects against} EAC cells

Then, we established the tumor burden after inoculation of EAC cells and the antitumor effects of treatment with CIS. The numbers of EAC cells were $133.25 \times 10^{6} \pm 40$ counted on day 7 and $2,921 \times 10^{6} \pm 1,271$ counted on day 14 of tumor inoculation (see Figure 1). Treatment of mice with 10 $\mu \mathrm{g} /$ mouse CIS induced a marked reduction in the tumor cell count $\left(68.35 \times 10^{6} \pm 45.35\right)$ on 7 days and $\left(44.15 \times 10^{6} \pm\right.$ 24.48) 14 days post treatment. As expected, the anti-tumor effect of treatment mice with $40 \mu \mathrm{g} / \mathrm{kg}$ CIS was higher than those obtained after treatment with $10 \mu \mathrm{g} / \mathrm{kg}$ CIS, where 
treatment with $40 \mu \mathrm{g} / \mathrm{kg}$ CIS for two weeks induced higher cessation of CIS.

anti-tumor $\left(14.86 \times 10^{6} \pm 3.73\right)$ effects than one week $(43.2$

$\left.\times 10^{6} \pm 29.1\right)$. However, the tumor cells grew back after
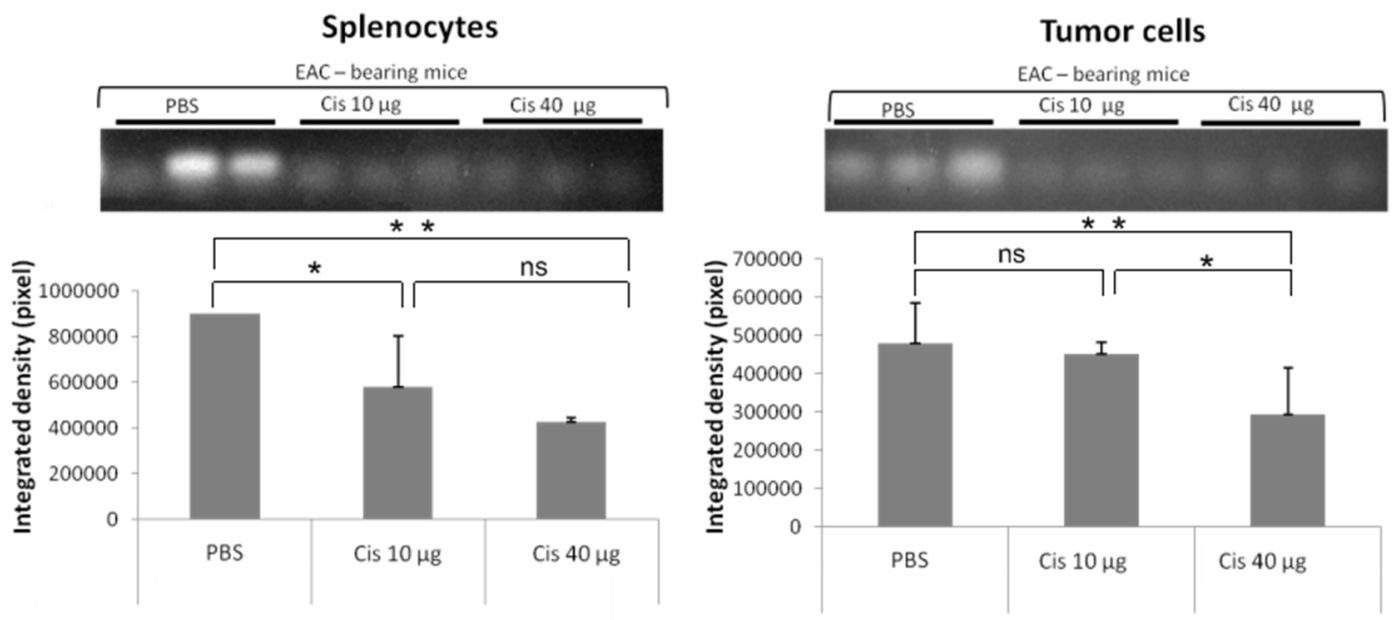

Figure 3. Effects of CIS on miRNA-146a gene expression in spleen and EAC after 1 week of EAC inoculation. CD1 mice $(\mathrm{n}=5)$ were i.p. inoculated with $10^{6}$ EAC on day 0 and treated with 10 or $40 \mu \mathrm{g}$ of CIS on days $1,3,4,5$, and 6 post EAC inoculation. Mice were then sacrificed on day 7. Total mRNA was extracted from spleen and tumor cells and the expression level of miRNA was determined relative to untreated tumor bearing mice. The experiment was performed in triplicate and the data are presented as mean $\pm S D$.
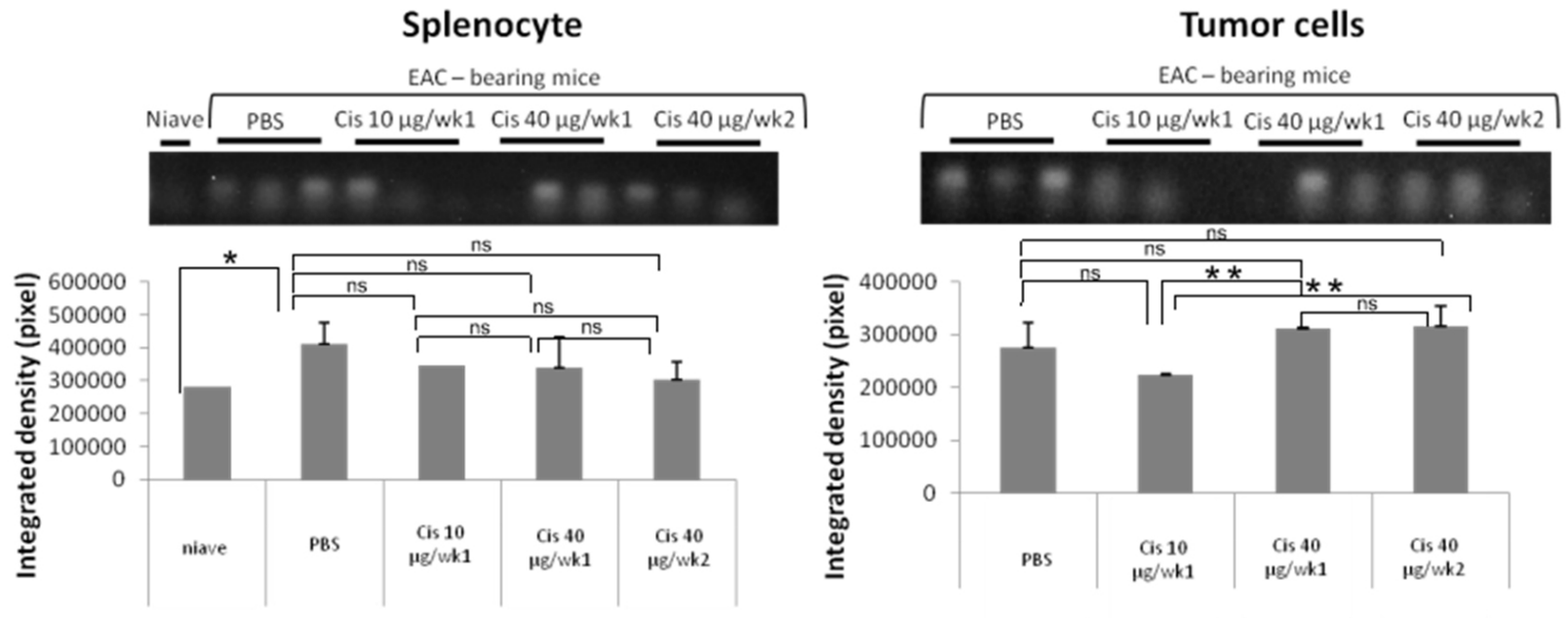

Figure 4. Effects of CIS on miRNA-146a gene expression in spleen and EAC after 2 weeks of EAC cells inoculation. Mice were treated with $10 \mu \mathrm{g}$ or $40 \mu \mathrm{g} /$ mouse CIS for two weeks. RNA of spleen and tumor cells was extracted 1 or 2 weeks post-treatment and the expression level of miRNA was determined relative to untreated tumor bearing mice. The experiment was performed in triplicate and data are presented as mean $\pm S D$.

\subsection{CIS treatment induced alteration in the numbers of splenocytes}

First, we established the effects of tumor on the number of splenocytes in presence or absence of chemotherapy. EAC burden was evaluated by counting the number of viable cells with or without treatment with different doses of CIS at early Published by Sciedu Press or late time of tumor inoculation. As shown in Figure 2, a significant decrease in spleen cell count was observed in control tumor-bearing mice after one week $(68.8 \pm 13.92)$ and two weeks $(36.67 \pm 11.2)$ of tumor inoculation as compared with mice with no tumor $(171.66 \pm 1.5)$. Treatment of mice with $10 \mu \mathrm{g}$ of CIS during the first week of tumor 
growth resulted in decreases in the number of spleen cells counted on days 7 (53.65 \pm 17.33$)$ and increased on days 14 (89.28 \pm 43.9$)$. Treatment of EAC-bearing mice with $40 \mu \mathrm{g}$ of CIS at this time points also induced similar effects on the total number of spleen cells counted on day $7(80 \pm 21.3)$ or day 14 (25.72 \pm 15.9$)$. Of note, treatment with $40 \mu \mathrm{g}$ CIS from days 7-13 resulted in a similar effects when the spleen cells were counted on day 14 of tumor inoculation $(46.75 \pm$ $32.15)$
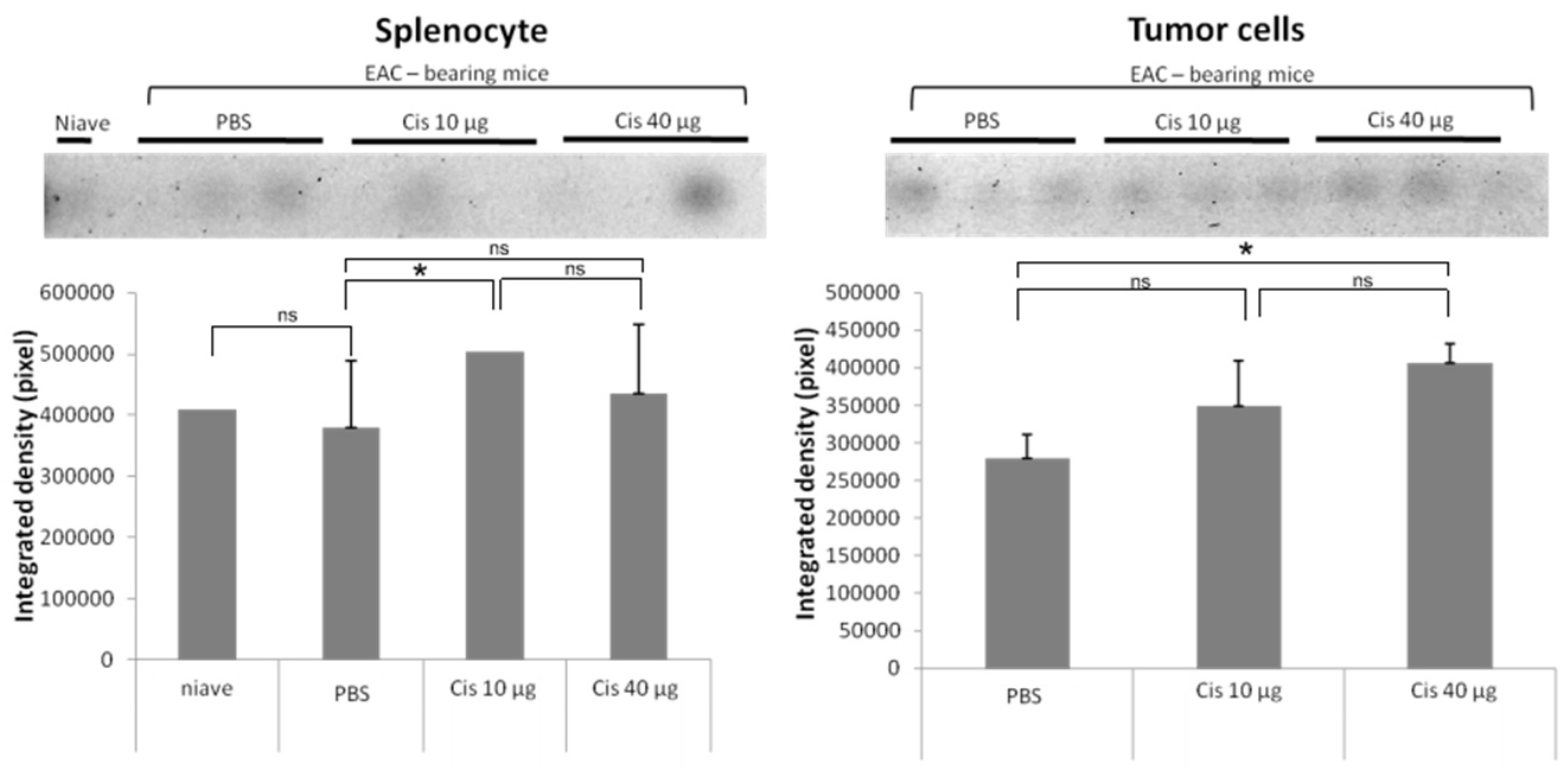

Figure 5. Effects of CIS on miRNA-155 gene expression in spleen and EAC after 1 week of EAC cells. Mice were treated with $10 \mu \mathrm{g}$ or $40 \mu \mathrm{g} /$ mouse CIS for two weeks. After one week post-treatment, RNA of spleen and tumor cells was extracted 1 week post-treatment and the expression level of miRNA was determined relative to untreated tumor bearing mice. The experiment was performed in triplicate and data are presented as mean $\pm S D$.
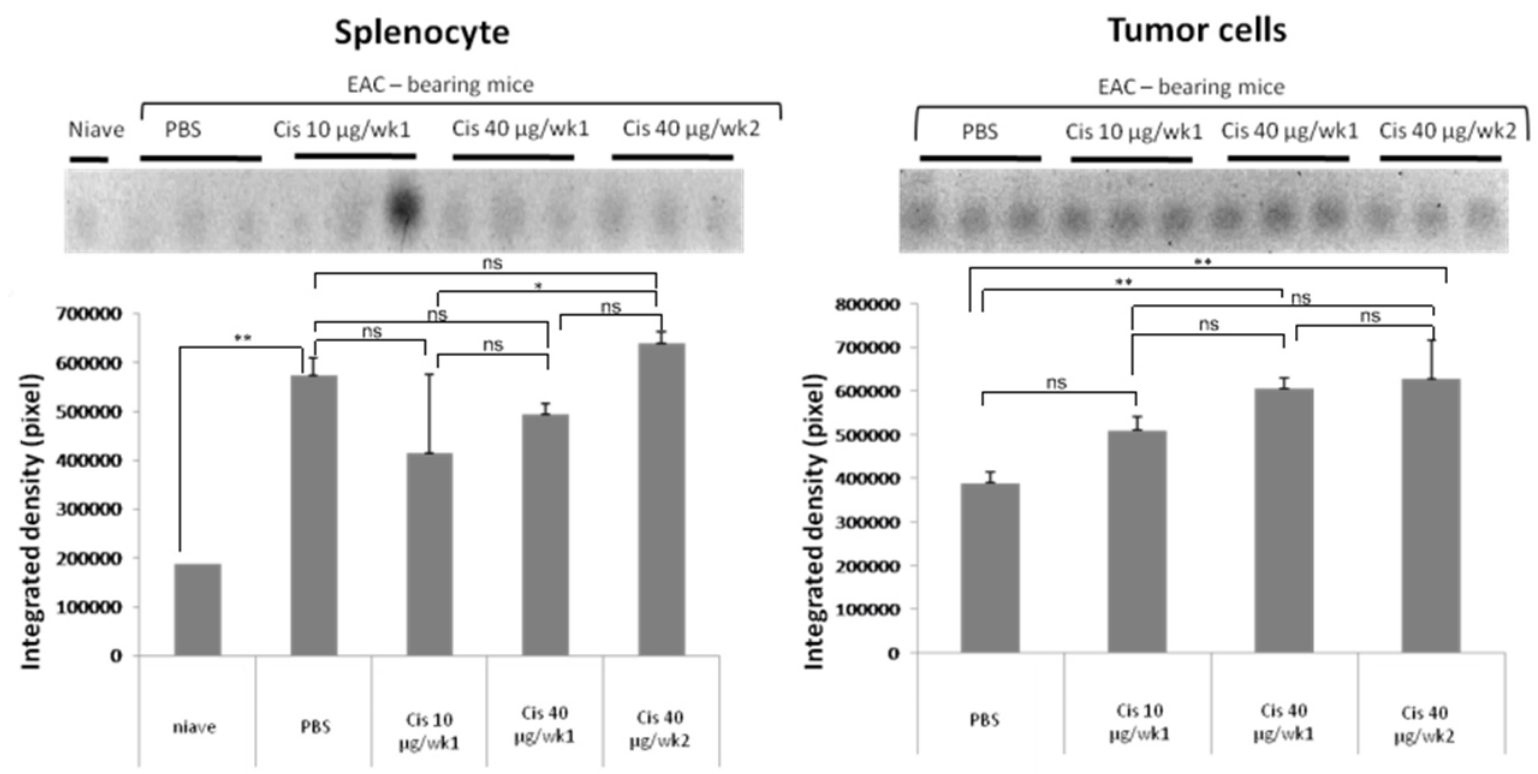

Figure 6. Effects of CIS on miRNA-155 gene expression in spleen and EAC after 2 weeks of EAC cell inoculation. Mice were treated with $10 \mu \mathrm{g}$ or $40 \mu \mathrm{g} /$ mouse CIS for two weeks. RNA of spleen and tumor cells was extracted 1 or 2 weeks post-treatment and the expression level of miRNA was determined relative to untreated tumor bearing mice. The experiment was performed in triplicate and data are presented as mean $\pm S D$. 


\subsection{CIS treatment induced alterations in miRNA expres- sion}

To examine the correlation between miRNA expression and tumor response to CIS therapy, we analyzed the gene expression of miRNA-155 and miRNA-146 in the presence or absence of CIS treatment at different time points using RTPCR. We used 10 and $40 \mu \mathrm{g} / \mathrm{mouse}$ CIS for either one week or two weeks and in both cases we quantified the expression level of miRNAs 24 hours and 7 days after the last treatment point of CIS.

We found decreases in the miRNA-146a expression level in both spleen and tumor cells of treated tumor-bearing mice as compared to its expression level in tumor-free mice and in untreated-tumor bearing mice when measured 1 week and 2 weeks after treatment (see Figures 3 and 4). On the other hand, the miRNA-155 expression level was considerably increased in spleen and tumor cells upon treatment with CIS in a dose-dependent manner (see Figures 5 and 6) as compared to tumor-free and untreated-tumor bearing mice.

To test whether tumor relapse after chemotherapy reversemiRNA expression level, RNA was extracted from treated tumor bearing mice one week and two weeks posttreatment followed by RT-PCR. Our results showed that treatment of EAC-bearing mice with $40 \mu \mathrm{g} / \mathrm{mouse}$ CIS induced decreases in the expression levels of miRNA-146a in spleen even after two week post-treatment but the expression level in tumor cells remains the same two week post-treatment. The expression level of miRNA-155 in the spleen of tumor-bearing mice treated with $40 \mu \mathrm{g} /$ mouse CIS slightly increased after two weeks post-treatment. In contrast, its expression level markedly increased in tumor cells after two weeks post treatment with a value of relative expression more than its expression in tumor-free and untreated-tumor bearing mice.

\section{DisCussion}

Our results reveal that in EAC-bearing mice, miRNA-155 expression level considerably increased in the spleen and tumor cells upon CIS treatment as compared to tumor-free and untreated-tumor bearing mice. In line with our results, clinical studies showed increases in the gene expression of miRNA-155 in breast cancer tissues. ${ }^{[21,22]}$ In line with this notion, miRNA-155 was found to be the most commonly up-regulated miRNAs in solid and hematological malignancies. $^{[23]}$

Not surprisingly, a tight control of miRNA-155 expression is required to avoid malignant transformation, as evidenced by miRNA-155 over expression in many cancers of B-cell origin. ${ }^{[23]}$ In the current study, we found that tumor itself Published by Sciedu Press induced increases in the miRNA-155 expression levels in spleen and tumor cells as compared to its expression in tumor-free and untreated tumor-bearing mouse. This effect increases with the tumor progression. Treatment with CIS as anticancer drug increased miRNA-155 transcription level. This effect was sustained even after two weeks post CIS treatment.

Similar to the modulatory effects of CIS on miRNA, the effects of other immunosuppressive drugs have also been reported. It was found in this study that the anti-inflammatory effects of hydroxychloroquine and prednisone in female NZB/W lupus mice are dependent on their capability to modulate the miRNA expression levels of miRNA, where these drugs induced reduction in miRNA-146a and miRNA-155 expression in plasmacytoid dendritic cells, they induced increases in miR-155 expression in $\mathrm{T}$ and $\mathrm{B}$ lymphocytes and monocytes. ${ }^{[24]}$ MiRNA-155 and -146a miRNAs were found to be upregulated in both purified splenic B and $\mathrm{T}$ cells from MRL-lpr mice with lupus. ${ }^{[25]}$ Similarly, miRNA-146a was decreased in freshly isolated splenic lymphocytes from estrogen-treated mice, where increasing its higher activity inhibited the LPS-induced IFN- $\gamma$ and iNOS expression in mouse splenic lymphocytes. ${ }^{[26]}$

Interestingly, the increased profile of miRNA was associated with increases in the numbers of spleen cells and reduction in the number of tumor cells, indicating that miRNA-155 might be involved in anticancer immune responses. This is likely to be possible since upregulation of miRNA-155 expression has been reported in activated immune cells. ${ }^{[27]}$ This suggested association between the increase in miRNA-155 expression and anti-tumor immunity could be explained by the increases in its expression under the effects of inflammatory stimuli. For instance, miRNA-155 expression was found to be induced by toll-like receptor (TLR) signals such as TLR2, TLR3, TLR4, and TLR9, or stimulation with cytokines such as IL-1, TNF- $\alpha$, and IFN- $\beta,{ }^{[12-14]}$ indicating to the involvement of miRNA-155 in enhancing immune responses. In the immune system, miRNA-155 was found to be unique in its ability to shape the transcriptome of activated myeloid and lymphoid cells controlling diverse biological functions ranging from inflammation to immunological memory. ${ }^{[28]}$ Although, we have not investigated its role in anti-EAC immunity, previous studies suggested a role for miRNA-155 in suppression of undesirable RNAs. For instance, it was found that RNA virus infection induces miRNA-155 expression in macrophages via retinoic acid-inducible gene I/JNK/NF-kB dependent pathway but TLR/MyD88-independent pathway, which promoted type I IFN signaling pathway and the suppression of viral replication. 
Opposite to miRNA-155, we found that tumor itself induces increases in the expression level of miRNA-146 as compared to its expression in tumor-free and untreated tumor-bearing mouse. This effect increases with the tumor progression. In line with our results, miRNA-146 was found to be highly expressed in the plasma and in tissues of non-small cell lung, ${ }^{[29]}$ oral squamous cell carcinoma ${ }^{[30]}$ and thyroid carcinoma tissues. ${ }^{[31]}$ Interestingly, these levels decreased after tumor surgery of oral squamous cell carcinoma. ${ }^{[30]}$

In the present study, treatment with CIS inhibited miRNA146a transcription levels both in spleen cells and in EAC cells at a dose of $10 \mu \mathrm{g} / \mathrm{mouse}$. At $40 \mu \mathrm{g} / \mathrm{mouse}$, however, CIS could not inhibit miRNA-146a expression level even when the treatment was lasted for two weeks. Indeed, miRNA$146 \mathrm{a}$ has been found to directly down-regulate the production of pro-inflammatory cytokines by acting as a negativefeedback effector on the inflammatory signaling pathway initiated by NF-kB and JAK STAT signaling pathway. ${ }^{[16]}$ These effects were suggested to be augmented by certain doses of anticancer treatments. Furthermore, ovalbumininduced asthma coincided with higher expression levels of miRNA-146a and -146b in CD4+ T cells immediately after the beginning of the disease. Treatment with dexamethasone under this setting induced down-regulation of the expression level of miRNA-146a associated with a positive linear correlation with the infiltration of the inflammatory cells into the inflammatory foci. ${ }^{[32]}$ As such, it could be suggested that miRNA-146a and -b are proinflammatory factors, where the effects of immunosuppressive anticancer drugs may be mediated by their ability to down-regulate miRNA-146a expression.

In contrast to its proinflammatory effects, miR-146a has also been found to act as a negative feedback regulator of inflammation. For instance, its absence in C57BL/6 mice leads to defined myeloid sarcomas and lymphomas which were associated with chronic myeloproliferation in bone marrow and with higher nuclear p65. ${ }^{33]}$ Similarly, miRNA-146a has been found to express a negative correlation with TNF- $\alpha$ in vitro secretion by monocytes derived from mice infected with periodontal pathogens; the effects was also associated with decreases in the downstream pathways including IRAK-1 and TRAF6. ${ }^{[34]}$

Recent studies indicated that miRNA-155 level can be used as a screening marker for various cancers. ${ }^{[35]}$ For in- stance, sera of colorectal cancer patients showed upregulated miRNA-155 expression level. ${ }^{[36]}$ Further, miRNA-155 was found to enhance proliferation and invasion capabilities of colon, ${ }^{[37]}$ prostate $^{[38]}$ and cervical ${ }^{[39]}$ and bladder cancers. ${ }^{[40]}$ MiRNA-155 targets SHIP1, an inhibitor of the PI3K/Akt pathway, resulted in monocytic differentiation and apoptosis and abolishes the anti-leukemic effects of epvonedistat. More importantly, reduction of miRNA-155 expression pharmacologically in vivo prolonged the survival of mice engrafted with leukemic cells. ${ }^{[41]}$

Knockdown of miRNA-155 sensitizes glioma cells to the chemotherapy with temozolomide and markedly inhibited lymphoproliferative disease by stimulating BIM-dependent CD4+ T cell apoptosis ${ }^{[42]}$ by targeting the MAPK13 and MAPK14-mediated oxidative stress and apoptosis. ${ }^{[43]}$ Further, murine cancer such as B16-F10 melanoma and Lewis lung carcinoma tumors were found to grow much quicker in miRNA-155-/- mice along with an increase of myeloidderived suppressor cells accumulation in tumors, which expressed higher migration capability and expression levels of multiple chemokines. ${ }^{[44]}$

Interestingly, recent studies reported that miRNA-155 is required for the antitumor responses of CD8+ T cells, ${ }^{[45]}$ where miRNA155-/- CD8+ T cells were ineffective at controlling tumor growth coincided with induction of suppressor of cytokine signaling-1 (SOCS-1) and the resultant deficiency in cytokine signaling. By contrast, over expression of miRNA155 resulted in enhancement of the antitumor adoptive immunotherapy to mediate profound antitumor responses even in absence of application of immune ablation. This enhanced T-cell responsiveness limited amounts of homeostatic $\gamma \mathrm{c}$ cytokines and resulted in delayed cellular contraction and sustained cytokine production.

Taken together, our results suggest that miRNA-155 and miRNA-146a might play contrasting effects on tumor and immune cells, where the transcription level of miRNA-146a decreased in EAC and spleen cells, the transcription level of miRNA-155 increased. These data shed a light on the impact of tumor burden and its responses to chemotherapy on micRNA expression.

\section{CONFlicts OF INTEREST Disclosure}

The author declares that there is no conflict of interest statement. 


\section{REFERENCES}

[1] Bartel DP. MicroRNAs: target recognition and regulatory functions. Cell. 2009; 136 (2): 215-33. PMid:19167326. http://dx.doi.o $\mathrm{rg} / 10.1016 / \mathrm{j} . \mathrm{cell} .2009 .01 .002$

[2] Alvarez-Garcia I, Miska EA. MicroRNA functions in animal development and human disease. Development. 2005; 132: 4653-62. PMid:16224045. http://dx.doi.org/10.1242/dev. 02073

[3] Espinosa SCE, Slack FJ. The role of microRNAs in cancer. Yale J Biol Med. 2009; 79(3-4): 131-40.

[4] Faraoni I, Antonetti FR, Cardone J, et al. MiR-155 gene: a typical multifunctional microRNA. Biochimica et biophysica acta. 2005; 1792(6): 497-505. PMid:19268705. http://dx.doi.org/10.10 $16 / \mathrm{j}$. bbadis .2009 .02 .013

[5] Lee RC, Feinbaum RL, Ambros V. The C. elegans heterochronic gene lin-4 encodes small RNAs with antisense. complementarity to lin-14. Cell. 1993; 75: 843-54. http://dx.doi.org/10.1016/0 092-8674 (93) 90529-Y

[6] Sassen S, Miska EA, Caldas C. MicroRNA-implications for cancer. Virchows Arch. 2008; 452(1): 1-10. PMid:18040713. http: //dx.doi.org/10.1007/s00428-007-0532-2

[7] Zhang P, Bill K, Liu J, et al. MiR-155 is a liposarcoma oncogene that targets casein kinase-1alpha and enhances beta-catenin signaling. Cancer Res. 2012; 72(7): 1751-62. PMid:22350414. http://dx.doi.org/10.1158/0008-5472.CAN-11-3027

[8] Kala R, Peek GW, Hardy TM, et al. MicroRNAs: an emerging science in cancer epigenetics. J Clin Bioinform. 2013; 3(1): 6. PMid:23497588. http://dx.doi.org/10.1186/2043-9113-3 $-6$

[9] Rodriguez AE, Vigorito S, Clare MV, et al. Requirement of bic/microRNA-155 for normal immune function. Science. 2007; 316: 608-11. PMid:17463290. http://dx.doi.org/10.1126/scien ce. 1139253

[10] Vigorito E, Perks KL, Abreu-Goodger C, et al. MicroRNA-155 regulates the generation of immunoglobulin class-switched plasma cells. Immunity. 2007; 27: 847-59. PMid:18055230. http://dx.doi.o rg/10.1016/j.immuni.2007.10.009

[11] Thai TH, Calado DP, Casola S, et al. Regulation of the germinal center response by microRNA-155. Science. 2007; 316: 6048. PMid:17463289. http://dx.doi.org/10.1126/science.1 141229

[12] O'Connell RM, Taganov KD, Boldin MP, et al. MicroRNA-155 is induced during the macrophage inflammatory response. Proc Nat Acad Sci USA. 2007; 104: 1604-9. PMid:17242365. http: //dx.doi.org/10.1073/pnas.0610731104

[13] Tili E, Michaille JJ, Cimino A, et al. MicroRNA-155 modulates the interleukin-1 signaling pathway in activated human monocytederived dendritic cells. Proc Nat Acad Sci USA. 2009; 106: 273540. PMid:19193853. http://dx.doi.org/10.1073/pnas.0811 073106

[14] Tili E, Michaille JJ, Adair B, et al. Resveratrol decreases the levels of miR-155 by upregulating miR-663, a microRNA targeting JunB and JunD. Carcinogen. 2010; 31(9):1561-6. PMid:20622002. http://dx.doi.org/10.1093/carcin/bgq143

[15] Taganov KD, Boldin MP, Chang KJ, et al. NF-kappaBdependent induction of microRNA miR-146, an inhibitor targeted to signaling proteins of innate immune responses. Proc Nat Acad Sci USA. 2006; 103(33): 12481-6. PMid:16885212. http://dx.doi.org/10.10 73/pnas. 0605298103

[16] Boldin MP, Taganov KD, Rao DS, et al. MiR-146a is a significant brake on autoimmunity, myeloproliferation, and cancer in mice. J Exp Med. 2011; 208: 1189-1201. PMid:21555486. http: //dx.doi.org/10.1084/jem. 20101823

Published by Sciedu Press
[17] Tomankova T, Petrek M, Gallo J, et al. MicroRNAs: emerging regulators of immune-mediated diseases. Scand J Immunol. 2012; 75: 129-41. PMid:21988491. http://dx.doi.org/10.1111/j.136 5-3083.2011.02650.x

[18] Liu Z, Xiao B, Tang B, et al. Up-regulated microRNA-146a negatively modulate Helicobacter pylori-induced inflammatory response in human gastric epithelial cells. Microbes Infect. 2010; 12: 85463. PMid:20542134. http://dx.doi.org/10.1016/j.micinf . 2010.06 .002

[19] Salem ML, Kadima AN, Cole DJ, et al. Defining the antigenspecific T-cell response to vaccination and poly (I: C)/TLR3 signaling: evidence of enhanced primary and memory CD8 T-cell responses and antitumor immunity. J Immunother. 2005; 28(3): 2208. PMid:15838378. http://dx.doi.org/10.1097/01.cji.00 $00156828.75196 .0 d$

[20] Iorio MV, Ferracin M, Liu CG. et al. MicroRNA gene expression deregulation in human breast cancer. Cancer Res. 2005; 65(16): 7065 70. PMid:16103053. http://dx.doi .org/10.1158/0008-5472. CAN-05-1783

[21] Lee YS, Dutta A. MicroRNAs in cancer. Annu Rev Pathol. 2009; 4 199-227. PMid:18817506. http://dx.doi.org/10.1146/annur ev.pathol.4.110807.092222

[22] Sandhu SK, Volinia S, Costinean S, et al. MiR-155 targets histone deacetylase 4 (HDAC4) and impairs transcriptional activity of B-cell lymphoma 6 (BCL6) in the Emu-miR-155 transgenic mouse model. Proc Nat Acad Sci USA. 2012; 109(49): 20047-52. PMid:23169640. http://dx.doi.org/10.1073/pnas. 1213764109

[23] Chafin CB, Regna NL, Hammond SE, et al. Cellular and urinary microRNA alterations in NZB/W mice with hydroxychloroquine or prednisone treatment. Int Immunopharmacol. 2013; 17(3): 894906. PMid:24121037. http://dx.doi.org/10.1016/j.intimp. 2013.09.013

[24] Dai R, Zhang Y, Khan D, et al. Identification of a common lupus disease-associated microRNA expression pattern in three different murine models of lupus. PLoS One. 2010; 5(12): e14302. PMid:21170274. http://dx.doi.org/10.1371/journal.pon e. 0014302

[25] Dai R, Phillips RA, Zhang Y, et al. Suppression of LPS-induced Interferon-gamma and nitric oxide in splenic lymphocytes by select estrogen-regulatedmicroRNAs: a novel mechanism of immune modulation. Blood. 2008; 112(12): 4591-7. PMid:18791161. http: //dx.doi.org/10.1182/blood-2008-04-152488

[26] Wang P, Hou J, Lin L, et al. Inducible microRNA-155 feedback promotes type I IFN signaling in antiviral innate immunity by targeting suppressor of cytokine signaling 1. J Immunol. 2010; 185(10): 6226-33. PMid:20937844. http://dx.doi.org/10.4049/jimmu nol. 1000491

[27] Vigorito E, Kohlhaas S, Lu D, et al. MiR-155: an ancient regulator of the immune system. Immunol Rev. 2013 May; 253(1): 146-57. PMid:23550644. http://dx.doi.org/10.1111/imr.12057

[28] Li J, Yang H, Li Y, et al. MicroRNA-146 up-regulation predicts the prognosis of non-small cell lung cancer by miRNA in situ hybridization. Exp Mol Pathol. 2014; 96(2): 195-9. PMid:24448024. http://dx.doi.org/10.1016/j.yexmp.2013.11.004

[29] Hung PS, Liu CJ, Chou CS, et al. MiR-146a enhances the oncogenicity of oral carcinoma by concomitant targeting of the IRAK1, TRAF6 and NUMB genes. PLoS One. 2013 Nov; 8(11): e79926. PMid:24302991. http://dx.doi.org/10.1371/journal.pon e.0079926

[30] Sun M, Fang S, Li W, et al. Associations of miR-146a and miR-146b expression and clinical characteristics in papillary thyroid carcinoma. Cancer Biomark. 2015; 15(1): 33-40. PMid:25524940. 
[31] Feng MJ, Shi F, Qiu C, et al. MicroRNA-181a, -146a and 146b in spleen CD4+ $\mathrm{T}$ lymphocytes playproinflammatory roles in a murine model of asthma. Int Immunopharmacol. 2012; 13(3): 34753. PMid:22580216. http://dx.doi.org/10.1016/j.intimp. 2012.05.001

[32] Zhao JL, Rao DS, Boldin MP, et al. NF-kappaB dysregulation in microRNA-146a-deficient mice drives the development of myeloid malignancies. Proc Natl Acad Sci USA. 2011; 108(22): 9184 9. PMid:21576471. http://dx.doi.org/10.1073/pnas.1105 398108

[33] Nahid MA, Rivera M, Lucas A, et al. Polymicrobial infection with periodontal pathogens specifically enhances microRNA miR-146a in ApoE-/- mice during experimental periodontal disease. Infect Immun. 2011; 79(4): 1597-605. PMid:21263019. http://dx.doi .org/10 . 1128/IAI . 01062-10

[34] Wu C, Liu Q, Liu B. MicroRNA-155 hallmarks promising accuracy for the diagnosis of various carcinomas: results from a meta-analysis. Dis Markers. 2015; 2015: 327287. PMid:25918453. http://dx.doi.org/10.1155/2015/327287

[35] Lv ZC, Fan YS, Chen HB, et al. Investigation of microRNA-155 as a serum diagnostic and prognostic biomarker for colorectal cancer. Tumour Biol. 2015 Mar; 36(3): 1619-25. PMid:25528214. http://dx.doi.org/10.1007/s13277-014-2760-9

[36] He B, Gao SQ, Huang LD, et al. MicroRNA-155 promotes the proliferation and invasion abilities of colon cancer cells by targeting quaking. Mol Med Rep. 2015; 11(3): 2355-9. PMid:25420938.

[37] Cai ZK, Chen Q, Chen YB, et al. MicroRNA-155 promotes the proliferation of prostate cancer cells by targeting annexin 7. Mol Med Rep. 2015; 11(1): 533-8. PMid:25339368.

[38] Lao G, Liu P, Wu Q, et al. MicroRNA-155 promotes cervical cancer cell proliferation through suppression of its target gene
LKB1. Tumour Biol. 2014 Dec; 35(12): 11933-8. PMid:25155037. http://dx.doi.org/10.1007/s13277-014-2479-7

[39] Peng Y, Dong W, Lin TX, et al. MicroRNA-155 promotes bladder cancer growth by repressing the tumor suppressor DMTF1. Oncotarget. 2015. http://dx.doi.org/10.18632/oncotarget.3755

[40] Khalife J, Radomska HS, Santhanam R, et al. Pharmacological targeting of miR-155 via the NEDD8-activating enzyme inhibitor MLN4924 (Pevonedistat) in FLT3-ITD acute myeloid leukemia. Leukemia. 2015: 14. http://dx.doi.org/10.1038/leu. 2015. 106

[41] Rouquette-Jazdanian AK, Kortum RL, Li W, et al. MiR-155 Controls Lymphoproliferation in LAT Mutant Mice by Restraining TCell Apoptosis via SHIP-1/mTOR and PAK1/FOXO3/BIM Pathways. PLoS One. 2015 Jun 29; 10(6): e0131823. PMid:26121028. http://dx.doi.org/10.1371/journal.pone.0131823

[42] Liu Q, Zou R, Zhou R, et al. MiR-155 Regulates Glioma Cells Invasion and Chemosensitivity by p38 Isforms In Vitro. J Cell Biochem. 2015 Jul; 116(7): 1213-21. PMid:25535908. http://dx.doi.org /10.1002/jcb. 25073

[43] Wang H, Men CP. Correlation of Increased Expression of MicroRNA155 in Bladder Cancer and Prognosis. Lab Med. 2015 Spring; 46(2): 118-22. PMid:25918190. http://dx.doi.org/10.1309/LMWR9 CEA2K2XVSOX

[44] Ji Y, Wrzesinski C, Yu Z, et al. MiR-155 augments CD8+ T-cell antitumor activity in lymphoreplete hosts by enhancing responsiveness to homeostatic $\gamma$ c cytokines. Proc Natl Acad Sci USA. 2015; 112(2): 476-81. PMid:25548153. http://dx.doi.org/10.1073 /pnas. 1422916112

[45] Dudda JC, Salaun B, Ji Y, et al. MicroRNA-155 is required for effector CD8+ T cell responses to virus infection and cancer. Immunity. 2013; 38(4): 742-53. 